\title{
Growth Performance, Carcass Yield, and Immune Competence of Broiler Chickens as Influenced by Dietary Supplemental Zinc Sources and Levels
}

\author{
K. Yogesh $\cdot$ Chandra Deo $\cdot$ H. P. Shrivastava $\cdot$ \\ A. B. Mandal $\cdot$ Ashutosh Wadhwa $\cdot$ Indira Singh
}

Received: 28 February 2012/ Accepted: 31 May 2013/Published online: 23 June 2013

(C) NAAS (National Academy of Agricultural Sciences) 2013

\begin{abstract}
This study was conducted to determine the effect of sources and levels of zinc ( $\mathrm{Zn}$ ) on growth performance, carcass characteristics, and immunocompetence of broilers. A 6-week (0-6 weeks of age) feeding trial was conducted as per $3 \times 4$ factorial design involving three $\mathrm{Zn}$ sources (zinc propionate- $\mathrm{ZnP}$, zinc oxide- $\mathrm{ZnO}$ and zinc sulfate- $\mathrm{ZnS}$ ) each with four levels of $\mathrm{Zn}(40,60,80$, and $100 \mathrm{mg} / \mathrm{kg}$ ) during starting (0-3 weeks) and finishing (4-6 weeks) phase in a standard broiler diet. Overall body weight gain, feed intake, feed conversion ratio, and percent $\mathrm{Zn}$ retention in broilers from 0 to 6 weeks were not differed significantly due to the interaction of different sources and levels of $\mathrm{Zn}$. Growth traits were non-significant due to the main effect of $\mathrm{Zn}$ level. Percent $\mathrm{Zn}$ retention was decreased due to increase in $\mathrm{Zn}$ levels ( $\mathrm{L}$ effect, $P<0.001$; Q effect-non-significant) among different groups. The humoral (HA titre to-SRBC) and cellular (foot pad index (FPI) to phytohaemagglutinin-P) immune response did not differ significantly due to main effect of $\mathrm{Zn}$ sources and interaction effect of $\mathrm{Zn}$ sources and levels. However, HA titre to SRBC was maximum $(P<0.05)$ at $80 \mathrm{mg} \mathrm{Zn} / \mathrm{kg}$ diet and FPI to PHA-P was maximum $(P<0.05)$ at $60 \mathrm{mg} \mathrm{Zn/kg} \mathrm{diet.} \mathrm{The} \mathrm{L} \mathrm{effect} \mathrm{of} \mathrm{Zn}$ level was non-significant for HA titre and FPI. The Q effect of $\mathrm{Zn}$ level was significant at $P<0.05$ and $P<0.01$ for HA titre and FPI, respectively.
\end{abstract}

Keywords Growth $\cdot$ Carcass quality $\cdot$ Immune competence $\cdot$ Broiler $\cdot$ Zinc

K. Yogesh $(\bowtie) \cdot$ C. Deo $~$ H. P. Shrivastava · A. B. Mandal Central Avian Research Institute, Izatnagar, Bareilly 243122, India

e-mail: ysomvanshi@gmail.com

Present Address:

K. Yogesh

Central Institute of Post Harvest Engineering and Technology,

Ludhiana, India

A. Wadhwa

Center for Wildlife Health, Department of Forestry, Wildlife and Fisheries, The University of Tennessee, Knoxville,

TN 37996-1071, USA

I. Singh

Banaras Hindu University, Varanasi, Uttar Pradesh, India

\section{Introduction}

Optimizing and updating nutrient requirements of poultry is a continuous process because of improved performance, variations in nutrient availability, interaction of different nutrients at sites of absorption and metabolism, and to achieve specialized designer products. Zinc $(\mathrm{Zn})$ is an essential trace mineral for normal growth/development of animal, and is involved in a variety of metabolic processes [19]. In poultry Zn plays a vital role in skin nucleic acid, keratin, collagen synthesis, and production and maintenance of epithelial cells. The $\mathrm{Zn}$ requirement of the chicks was first defined to be $30 \mathrm{mg} / \mathrm{Kg}$ [17]. Subsequently, the NRC [15] has recommended that the broiler diet should contain $40 \mathrm{ppm} \mathrm{Zn}$, which appeared to be based on the results that considered growth performance as the only criterion $[4,20]$. However, higher levels of $\mathrm{Zn}$ are supplemented in diets for enhancing immune response in chicken but the fortification of diets with excess minerals 
may cause antagonism affecting mineral bioavailability and masking the advantages of supplementation [7].

In view of the above, the effect of supplemental $\mathrm{Zn}$ sources and levels in relation to the growth performance, carcass yield, and immune competence in broiler chickens was studied during 6 weeks experimental period.

\section{Materials and Methods}

\section{Experimental Design}

A total of 252 broiler chicks were randomly allotted to cabins or tiers of the electrically heated battery brooders with the provision of wire-mesh floor, feeder, and waterer, located in the well-ventilated room, with uniform management. The chicks had free access to feed and water throughout 6 weeks (wks) feeding period.

Twelve dietary treatments with three $\mathrm{Zn}$ sources $(\mathrm{Zn}$ propionate- $\mathrm{ZnP}, \mathrm{Zn}$ oxide- $\mathrm{ZnO}$, and $\mathrm{Zn}$ sulfate- $\mathrm{ZnS}$ ) and four levels $(40,60,80$, and $100 \mathrm{mg} / \mathrm{kg})$ of each source were evaluated with triplicate lot of seven broiler chicks, accommodating 21 broiler chicks per treatment. As shown in Table 1 corn soybean basal diet was formulated and the final $\mathrm{Zn}$ content of each diet was set with the addition of $\mathrm{Zn}$ content of basal diet plus supplemented $\mathrm{Zn}$ content. Thus, different $\mathrm{ZnP}, \mathrm{ZnO}$, and $\mathrm{ZnS}$ were added to achieve final $\mathrm{Zn}$ contents of 40, 60, 80, and $100 \mathrm{ppm} \mathrm{Zn}$ in both starter and finisher diet. Birds were fed starter diet for the initial 21 days followed by finisher diet for next 21 days.

\section{Determination of Proximate Principal of Feed Ingredients and Diets}

The representative samples of feed ingredients and test diets used in the study were analyzed for moisture, crude protein (CP), total phosphorus (TP); [2], calcium [22], and Zn content [2] using atomic absorption spectrometer (AAS, Varian SpectrAA $220 \mathrm{Model}$ ). The ingredients and nutrient composition of basal diet used during starting (0-3 weeks) and finishing phase (4-6 weeks) have been presented in Table 1.

\section{Growth Traits, Mortality, and Zn Retention}

The overall body weight gain (BWG), feed intake (FI), feed conversion ratio (FCR) were recorded during 0-6 weeks. Daily monitoring and recording on individual basis was carried out to study the mortality among experimental birds. Two birds per replicate, thus six birds from each treatment were selected randomly and a 3-day balance study was conducted from 38 to 40 days of age during which the net feed consumed by each bird in the respective dietary group was recorded and the dropping voided over
Table 1 Ingredient and nutrient composition of basal diet used during starting phase (0-3 weeks) and finishing phase (4-6 weeks)

\begin{tabular}{|c|c|c|}
\hline \multirow[t]{2}{*}{ Ingredients } & \multicolumn{2}{|c|}{ Composition (\%) } \\
\hline & $\begin{array}{l}\text { Starting phase } \\
\text { (0-3 weeks) }\end{array}$ & $\begin{array}{l}\text { Finishing phase } \\
\text { (4-6 weeks) }\end{array}$ \\
\hline Yellow maize & 57.5 & 64.6 \\
\hline Deoiled rice bran & 4.9 & 4.8 \\
\hline Soybean meal & 34.2 & 27.2 \\
\hline Limestone powder & 0.5 & 0.5 \\
\hline Dicalcium phosphate & 2 & 2 \\
\hline DL-Methionine & 0.11 & 0.1 \\
\hline Lysine & 0.09 & 0.1 \\
\hline Common salt & 0.4 & 0.4 \\
\hline Trace mineral premix ${ }^{\mathrm{a}}$ & 0.15 & 0.15 \\
\hline Vitamin premix ${ }^{\mathrm{b}}$ & 0.15 & 0.15 \\
\hline \multicolumn{3}{|c|}{ Nutrient composition—analyzed (\% DM) } \\
\hline Crude protein & 22.5 & 19.49 \\
\hline Calcium & 1.05 & 1.18 \\
\hline Total phosphorus & 0.71 & 0.73 \\
\hline Zinc $(\mathrm{mg} / \mathrm{kg})^{\mathrm{c}}$ & 30 & 28 \\
\hline \multicolumn{3}{|l|}{ Calculated (\%) } \\
\hline $\mathrm{ME}(\mathrm{KCal} / \mathrm{kg})$ & 2850 & 2927 \\
\hline Available phosphorus & 0.5 & 0.5 \\
\hline Lysine & 1.2 & 1.2 \\
\hline Methionine & 0.5 & 0.5 \\
\hline
\end{tabular}

${ }^{a}$ Trace mineral mixture provided $(\mathrm{mg} / \mathrm{kg}$ diet $) \mathrm{Cu}-7.25 \mathrm{mg}$, $\mathrm{Fe}-80 \mathrm{mg}, \mathrm{I}-1.2 \mathrm{mg}, \mathrm{Mn}-65 \mathrm{mg}, \mathrm{Zn}$ - variable

b Vitamin mixture provided ( $\mathrm{mg} / \mathrm{kg}$ diet): Choline Chloride-500, Niacin-12, Pyridoxine Hydrochloride-1.6, Vitamin A-8250 IU, Vitamin $\mathrm{B}_{1}-0.8$, Vitamin $\mathrm{B}_{2}-5$, Vitamin $\mathrm{B}_{12}-8$, Vitamin $\mathrm{D}_{3}-1200$ IU, Vitamin $\mathrm{E}-10$ and Vitamin $\mathrm{K}-1$

c Further supplemented with four desired $\mathrm{Zn}$ levels to achieve 40, 60, 80, and $100 \mathrm{mg} \mathrm{Zn/kg} \mathrm{diet} \mathrm{from} \mathrm{each} \mathrm{of} \mathrm{three} \mathrm{Zn}$ sources

the same period were collected to estimate $\% \mathrm{Zn}$ retention. The total excreta voided from six replicates per treatment were collected to estimate the concentration of $\mathrm{Zn}$.

\section{Evaluation of Carcass Yield Factors}

At the end of experiment (42 days), two birds per replicate, thus six birds from each treatment were selected randomly by maintaining average body weight, slaughtered, and defeathered by machine. These six birds represented as six replicates in each treatment and evaluated for different carcass yield parameters.

Immune Response

The immune response of broiler chicks fed different supplemental $\mathrm{Zn}$ levels and sources were analyzed by the 
humoral immune response and cell-mediated immune response on completing 3 and 4 weeks of age, respectively. For this 72 chicks (6 chicks per treatment) were selected.

\section{Humoral Immune Response}

Modified method of Allan and Gough [1] was followed for assaying the immune response to sheep red blood cells ( $1 \%$ SRBC) at 21 days of feeding trial and blood was collected $72 \mathrm{~h}$ post SRBC injection. The antibody titre was determined by haemagglutination test (HA) in which microliter plates with $\mathrm{U}$ bottom were used. $50 \mu \mathrm{l}$ of PBS was distributed in each well of the plate. Same amount of serum was added in the first well. Two-fold serial dilutions were made up to 11th well, 12th well being the control. Then, $50 \mu \mathrm{l}$ of $1 \%$ SRBC in PBS was added to each well and mixed. The plates were covered and kept at $37{ }^{\circ} \mathrm{C}$ for $1 \mathrm{~h}$ for incubation. The plates were read under bright light. The reciprocal of the highest dilution showing clear agglutination was the end titre.

\section{Cell-Mediated Immune Response}

In vivo cell-mediated immune response to PHA-P was evaluated at 28 days of age by the method [9]. PHA-P $0.1 \mathrm{ml}(1 \mathrm{mg} / \mathrm{ml}$ in sterile phosphate buffer saline, PBS $)$ was injected intradermally in inter-digital space between 3rd and 4th toe of the right foot of the individual chick. The left foot served as controls and received the same amount of sterile PBS. The individual skin index for the right and left foot was calculated as the difference between the skin thicknesses measured by micrometer before and after $24 \mathrm{~h}$ of injection and expressed as millimeters. FPI was determined as the difference in skin index of right and left foot for individual bird.

\section{Statistical Analysis}

The data pertaining to various parameters were analyzed statically as general linear model with multivariate analysis. The significant mean differences were tested as per Duncan's multiple range test (DMRT). Polynomial linear (L) and quadratic $(\mathrm{Q})$ contrasts were used to test the effect of levels of $\mathrm{Zn}$ on immune parameters.

\section{Results and Discussion}

Growth Traits, \% Zn Retention, and Mortality

In the present study the overall BWG, FI, FCR, and percent $\mathrm{Zn}$ retention in broilers from 0 to 6 weeks were not differed significantly due to the interaction of different sources and levels of $\mathrm{Zn}$. Due to the main effect of $\mathrm{Zn}$ source FI and FCR were differed significantly (Table 2). The FI were more $(P<0.05)$ in $\mathrm{ZnO}$ group than other two groups and FCR were better $(P<0.05)$ in $\mathrm{ZnP}$ group. Again all the growth traits were non-significant due to the main effect of $\mathrm{Zn}$ level except for $\% \mathrm{Zn}$ retention which was decreased as $Z n$ level were increased (L effect, $P<0.001$; Q effectnonsignificant) in different groups. Non-significant interaction between $\mathrm{Zn}$ sources and $\mathrm{Zn}$ levels as seen in the present study is in close agreement with earlier observation reported by Mohanna and Nys [14] who did not observe any significant interaction between $\mathrm{Zn}$ sources and levels on BWG of broiler chicks and concluded that a dietary $\mathrm{Zn}$ concentration above $45 \mathrm{mg} / \mathrm{kg}$ did not give additional response in terms of BWG. Collins and Moran [7, 8] also reported that when dietary $\mathrm{Zn}$ concentrations are provided in excess of NRC recommendation of $40 \mathrm{mg} / \mathrm{kg}$ supplemental $\mathrm{Zn}$, growth rate remained unaffected. The present results received support from the earlier report of Collins and Moran [7, 8], who observed that the FCR was not improved at dietary levels of $\mathrm{Zn}$ exceeding the NRC recommendations of $40 \mathrm{mg} / \mathrm{kg}$ diet. Present results on $\mathrm{Zn}$ retention received support from the earlier work reported by Stahl et al. [21], who reported that chicks given either moderate or excess $\mathrm{Zn}$, excreted more than twice as much $\mathrm{Zn}$ from a test diet as those fed on the control diet. Furthermore, the high dietary $\mathrm{Zn}$ explained the low percentage of $\mathrm{Zn}$ retention as body $\mathrm{Zn}$ concentration remained stable when dietary $\mathrm{Zn}$ was higher than $60 \mathrm{mg} / \mathrm{kg}$. Similarly, Burrell et al. [5] reported that increased supplemental $\mathrm{Zn}$ concentration significantly increased the $\mathrm{Zn}$ excretion and reduced $\mathrm{Zn}$ utilization in experimental chicks. In the present study the $\mathrm{ZnP}$ had better $\mathrm{Zn}$ retention numeric value than inorganic sources $\mathrm{ZnO}$ and $\mathrm{ZnS}$. These results can be corroborated with earlier work reported by Wedekind et al. [23], who observed that in production animals, organic $\mathrm{Zn}$ sources such as $\mathrm{Zn}$ methionine or $\mathrm{Zn}$ propionate are significantly more bioavailable than inorganic $\mathrm{Zn}$ sources such as $\mathrm{Zn}$ oxide or $\mathrm{Zn}$ sulfate. Contrary to present finding, Burrell et al. [5] reported that the $\mathrm{Zn}$ sources either organic or inorganic did not alter $\mathrm{Zn}$ utilization. The overall mortality of the chicks in present study was $4.76 \%$ and there was no difference in the mortality due to the treatments.

\section{Carcass Yield Factors}

The various carcass yield factors (live weight, shrinkage loss, blood loss, feather loss, dressed weight, and eviscerated weight) and organ weight (giblet, heart, liver, and gizzard) did not differ significantly due to interaction between $\mathrm{Zn}$ sources and Zn levels. Similarly, carcass yield and organ weight did not differ statistically due to different 

parameters of broiler fed different sources and levels of zinc

Values containing common superscripts within a column are

$B W G$ body weight gain, $F I$ feed intake, $F C R$ feed conversion ratio, $F P I$ foot pad index, $Z n$ zinc, $\mathrm{ZnP}$ zinc propionate, $\mathrm{ZnO}$ zinc oxide, $Z n S$ zinc sulfate
Table 2 Growth and immune non-significant $(P<0.05)$

\begin{tabular}{|c|c|c|c|c|c|c|c|}
\hline \multirow{2}{*}{\multicolumn{2}{|c|}{$\begin{array}{l}\text { Treatments } \\
\text { Interaction effect }(n=21) \\
(\mathrm{Zn} \text { sources } \times \mathrm{Zn} \text { levels })\end{array}$}} & \multicolumn{6}{|l|}{ Parameters } \\
\hline & & \multirow{2}{*}{$\begin{array}{l}\text { BWG }(\mathrm{g}) \\
1130\end{array}$} & \multirow{2}{*}{$\begin{array}{l}\text { FI }(g) \\
2587\end{array}$} & \multirow{2}{*}{$\begin{array}{l}\text { FCR } \\
2.29\end{array}$} & \multirow{2}{*}{$\begin{array}{l}\begin{array}{l}\mathrm{Zn} \\
\text { retention }(\%)\end{array} \\
45.43\end{array}$} & \multirow{2}{*}{$\begin{array}{l}\text { HA } \\
\text { Titre }(\log 2) \\
5.00\end{array}$} & \multirow{2}{*}{$\begin{array}{l}\text { FPI } \\
(\mathrm{mm})\end{array}$} \\
\hline $\mathrm{ZnP}$ & 40 & & & & & & \\
\hline & 60 & 1132 & 2592 & 2.30 & 33.67 & 7.50 & 0.85 \\
\hline & 80 & 1141 & 2621 & 2.30 & 29.97 & 7.67 & 0.75 \\
\hline & 100 & 1079 & 2497 & 2.32 & 26.19 & 6.67 & 0.62 \\
\hline \multirow[t]{4}{*}{$\mathrm{ZnO}$} & 40 & 1127 & 2630 & 2.33 & 41.14 & 6.50 & 0.48 \\
\hline & 60 & 1076 & 2554 & 2.38 & 35.44 & 8.33 & 0.81 \\
\hline & 80 & 1075 & 2664 & 2.48 & 30.19 & 9.33 & 0.76 \\
\hline & 100 & 1078 & 2613 & 2.43 & 20.43 & 7.83 & 0.55 \\
\hline \multirow[t]{4}{*}{$\mathrm{ZnS}$} & 40 & 1110 & 2551 & 2.30 & 39.27 & 5.83 & 0.52 \\
\hline & 60 & 1098 & 2548 & 2.32 & 38.25 & 8.00 & 0.77 \\
\hline & 80 & 1096 & 2535 & 2.32 & 27.68 & 8.16 & 0.80 \\
\hline & 100 & 1115 & 2585 & 2.31 & 23.58 & 7.00 & 0.63 \\
\hline Pooled SEM & & 6.45 & 11.02 & 0.01 & 2.27 & 0.35 & 0.03 \\
\hline \multicolumn{8}{|l|}{ Main effects } \\
\hline \multirow[t]{3}{*}{ Zinc sources $(n=84)$} & $\mathrm{ZnP}$ & 1120 & $2574^{\mathrm{ab}}$ & $2.30^{\mathrm{b}}$ & 33.81 & 6.71 & 0.66 \\
\hline & $\mathrm{ZnO}$ & 1089 & $2615^{\mathrm{a}}$ & $2.41^{\mathrm{a}}$ & 31.80 & 8.00 & 0.65 \\
\hline & $\mathrm{ZnS}$ & 1105 & $2555^{\mathrm{b}}$ & $2.31^{\mathrm{b}}$ & 32.20 & 7.25 & 0.68 \\
\hline \multirow[t]{4}{*}{ Zinc levels $(n=63)$} & 40 & 1122 & 2589 & 2.31 & $41.95^{\mathrm{a}}$ & $5.78^{\mathrm{b}}$ & $0.48^{\mathrm{c}}$ \\
\hline & 60 & 1102 & 2565 & 2.33 & $35.79^{\mathrm{b}}$ & $7.94^{\mathrm{a}}$ & $0.81^{\mathrm{a}}$ \\
\hline & 80 & 1103 & 2607 & 2.37 & $29.28^{\mathrm{c}}$ & $8.39^{\mathrm{a}}$ & $0.77^{\mathrm{ab}}$ \\
\hline & 100 & 1092 & 2565 & 2.35 & $23.40^{\mathrm{d}}$ & $7.17^{\mathrm{ab}}$ & $0.60^{\mathrm{bc}}$ \\
\hline
\end{tabular}

dietary sources and levels of $\mathrm{Zn}$, whereas the average shrinkage loss due to fasting differed significantly $(P<0.01)$ due to different dietary $\mathrm{Zn}$ sources. Significantly, lower shrinkage loss value was observed in $\mathrm{ZnS}$ than $\mathrm{ZnP}$ and $\mathrm{ZnO}$. Present results received support from the earlier report of Collins and Moran [8] who also reported that the broiler fed with inorganic $\mathrm{Zn}$ at levels exceeding NRC recommendations did not alter carcass weight after processing at 49 days. These authors also reported that supplementing broiler feed with substantial levels of inorganic $\mathrm{Zn}$ generally did not improve processing yield of different broiler strains. Furthermore, the carcass yield was not influenced by supplemental $\mathrm{Zn}$ above $40 \mathrm{mg} / \mathrm{kg}$ diet. Rossi et al. [18] also stated that carcass yields were not influenced by providing increasing levels of dietary organic $\mathrm{Zn}$ to broilers.

Immune Response

Humoral and cellular immune response did not differ significantly due to $\mathrm{Zn}$ sources and interaction between $\mathrm{Zn}$ sources and Zn levels (Table 2). However, Humoral and cellular immune response differed significantly $(P<0.05)$ due to different dietary $\mathrm{Zn}$ levels. HA titre was significantly $(P<0.05)$ higher at $80 \mathrm{mg} \mathrm{Zn} / \mathrm{kg}$ diet and FPI was significantly $(P<0.05)$ higher at $60 \mathrm{mg} \mathrm{Zn} / \mathrm{kg}$ diet than other levels, whereas the diet having $100 \mathrm{mg} \mathrm{Zn} / \mathrm{kg}$ both immune parameters were found intermediary. The contrast

Table 3 Effects of zinc levels $(n=63)$ on the immune parameters of broiler chicks

\begin{tabular}{|c|c|c|c|c|c|c|c|}
\hline \multirow[t]{2}{*}{ Parameters } & \multicolumn{4}{|c|}{ Zinc levels } & \multicolumn{3}{|c|}{ Contrast } \\
\hline & 40 & 60 & 80 & 100 & SEM & $\mathrm{L}$ & Q \\
\hline HA titre $(\log 2)$ & $5.78^{\mathrm{b}}$ & $7.94^{\mathrm{a}}$ & $8.39^{\mathrm{a}}$ & $7.17^{\mathrm{ab}}$ & 0.35 & NS & $*$ \\
\hline Foot pad index (mm) & $0.48^{\mathrm{c}}$ & $0.81^{\mathrm{a}}$ & $0.77^{\mathrm{ab}}$ & $0.60^{\mathrm{bc}}$ & 0.03 & NS & $* *$ \\
\hline
\end{tabular}

Values containing common superscripts within a row are non-significant $(P<0.05)$

$N S$ non-significant, $L$ linear, $Q$ quadratic

$* P<0.05, * * P<0.01$ 
effect of $\mathrm{Zn}$ levels on the immune parameters is presented in Table 3. As the $\mathrm{Zn}$ level was increased, the HA titre increased up to $80 \mathrm{mg} / \mathrm{kg} \mathrm{Zn} \mathrm{level} \mathrm{but} \mathrm{again} \mathrm{decreased} \mathrm{at}$ $100 \mathrm{mg} / \mathrm{kg} \mathrm{Zn} \mathrm{level.} \mathrm{The} \mathrm{L} \mathrm{effect} \mathrm{was} \mathrm{non-significant} \mathrm{and}$ the $\mathrm{Q}$ effect was significant at $P<0.05$ for HA titre. The increase in $\mathrm{Zn}$ level led to increase the FPI from 40 to $60 \mathrm{mg} / \mathrm{kg} \mathrm{Zn} \mathrm{level} \mathrm{but} \mathrm{a} \mathrm{continuous} \mathrm{drop} \mathrm{in} \mathrm{FPI} \mathrm{was}$ observed after $60 \mathrm{mg} / \mathrm{kg} \mathrm{Zn} \mathrm{level} \mathrm{in} \mathrm{a} \mathrm{quadratic} \mathrm{manner} \mathrm{(Q,}$ $P<0.01)$.

Present results on immune parameters are in agreement with earlier report [6], where optimum supplemental level of $\mathrm{Zn}$ was suggested to be $80-120 \mathrm{mg} / \mathrm{kg}$ diet for broiler chickens to maximize immune response. Supplementing the $\mathrm{Zn}$ in diets fed to broiler breeder and turkey hens increased the cellular immune response of progeny as measured by cutaneous basophil hypersensitive tests $[12,13]$. Similarly, earlier researchers $[3,10]$ reported that the immune response of broilers can be affected by the levels of ZnAA in the diet. Khajarem et al. [11] reported that high level of $\mathrm{Zn}$ supplementation ( 75 verses $175 \mathrm{mg} / \mathrm{Kg}$ ) resulted in higher antibody titre to viral diseases in broiler breeder hens.

Contrary to present finding, some researchers reported that $\mathrm{Zn}$ concentration did not affect antibody titres of broilers in response to SRBC injections [14]. In agreement with these data Pimentel et al. [16] indicated that dietary $\mathrm{Zn}$ concentration $(8-58 \mathrm{mg} / \mathrm{Kg}$ ) or source ( $\mathrm{Zn}$ methionine or $\mathrm{ZnO}$ ) did not influence antibody titres to human gamma globulin or delayed-type hypersensitivity to phytohaemagglutinine in broilers.

\section{Conclusions}

The optimum supplemental level of $\mathrm{Zn}$ should be 60-80 mg/kg diet for broiler chickens to get better immune response. However, the zinc source did not significantly influence zinc utilization. Most of the growth and carcass yield factors were found to be non-significant due to different $\mathrm{Zn}$ sources and their levels.

\section{References}

1. Allan WH, Gough RE (1976) A comparison between the haemagglutination inhibition and complement fixation tests for new castle disease. Res Vet Sci 20(1):101-103

2. Association of Official Analytical Chemists (1990) Official methods for analysis of the Association of Official Analytical Chemists, 15th edn. Association of Offical Analytical Chemists, Arlington

3. Bartlett Smith M (2003) Effects of different levels of zinc on the performance and immunocompetence of broilers under heat stress. Poult Sci 82(10):1580-1588
4. Burrell AL, Dozier WA, Davis AJ, Compton MM, Freeman ME, Vendrell PF, Ward TL (2004) Responses of broilers to dietary zinc concentrations and sources in relation to environmental implications. Br Poult Sci 45:255-263

5. Burrell AL, Dozier WA, Davis AJ, Compton MM, Freeman ME, Vendrell PF, Ward TL (2004) Responses of broilers to dietary zinc concentrations and sources in relation to environmental implications. Br Poult Sci 45:255-263

6. Chunshan Zhang, Wenjin Zhu, Xuemin Guan, Jinchang Song (2006) Effect of interaction between dietary zinc and vitamin A in broilers on performance, immunity, ALP and CuZn-SOI activity and serum insulin concentration. World J Zoology 1(1):17-23

7. Collins NE, Moran ET (1999) Influence of supplemental manganese and zinc on live performance and carcass quality of broilers. J Appl Poult Res 8(2):222-227

8. Collins NE, Moran ET (1999) Influence of supplemental manganese and zinc on live performance and carcass quality of diverse broiler strains. J Appl Poult Res 8(2):228-235

9. Corrier DE, Deloach JR (1990) Evaluation of cell-mediated, cutaneous basophil hypersensitivity in young chickens by an interdigital skin test. Poult Sci 69(3):403-408. doi:10.3382/ps. 0690403

10. Hudson BP, Dozier WA, Fairchild BD, Wilson JL, Sander JE, Ward TL (2004) Live Performance and immune responses of straight-run broilers: influences of zinc source in broiler breeder hen and progeny diets and ambient temperature during the broiler production period. J Appl Poult Res 13(2):291-301

11. Khajarem J, Ratanasethalul C, Kharajarem S, Ward TL, Fakler TM, Johnson AB (2002) Effect of zinc and manganese amino acid complexes (availa $\mathrm{Z} / \mathrm{M}$ ) on broiler breeder production and immunity. Poult Sci 81(Suppl. 1):40(Abstr)

12. Kidd MT, Ferket PR, Qureshi MA (1996) Zinc metabolism with special reference to its role in immunity. World Poult Sci J 52:309-323

13. Kidd MT, Qureshi MA, Ferket PR, Thomas LN (2000) Turkey hen zinc source affects progeny immunity and disease resistance. J Appl Poult Res 9:414-423

14. Mohanna C, Nys Y (1999) Effect of dietary zinc content and sources on the growth, body zinc deposition and retention, zinc excretion and immune response in chickens. Br Poult Sci 40(1):108-114. doi:10.1080/00071669987926

15. National Research Council (1994) Nutrient requirements of poultry, 9th edn. Natational Academy Press, Washington, DC

16. Pimentel JL, Cook ME, Greger JL (1991) Immune response of chicks fed various levels of zinc. Poult Sci 70(4):947-954. doi: $10.3382 /$ ps.0700947

17. Roberson RH, Schaible PJ (1958) The zinc requirement of the chick. Poult Sci 37(6):1321-1323. doi:10.3382/ps.0371321

18. Rossi P, Rutz F, Anciuti MA, Rech JL, Zauk NHF (2007) Influence of graded levels of organic zinc on growth performance and carcass traits of broilers. J Appl Poult Res 16:219-225

19. Salim HM, Jo C, Lee BD (2008) Zinc in broiler feeding and nutrition. Avian Biol Res 1(1):5-18. doi:10.3184/175815508x 334578

20. Stahl JL, Cook ME, Sunde ML (1986) Zinc supplementation: its effect on egg production, feed conversion, fertility, and hatchability. Poult Sci 65(11):2104-2109. doi:10.3382/ps.0652104

21. Stahl JL, Cook ME, Sunde ML, Greger JL (1989) Enhanced humoral immunity in progeny chicks from hens fed practical diets supplemented with zinc. Appl Agric Res 4:86-89

22. Talpatra SK, Ray SC, Sen KC (1940) Estimation of phosphorus, choline, calcium, magnesium, sodium, potassium in feeding stuffs. J Vet Sci Anim Husb 10:243-245

23. Wedekind KJ, Hortin AE, Baker DH (1992) Methodology for assessing zinc bioavailability: efficacy estimates for zinc methionine, zinc sulfate, and zinc oxide. J Anim Sci 70:178-187 